\title{
A Novel Glycosphingolipid That May Participate in Embryo Inversion in Volvox carteri
}

\author{
Stephan Wenzl and Manfred Sumper \\ Lehrstuhl Biochemie I \\ Universität Regensburg, Universitätsstr. 31 \\ 8400 Regensburg \\ Federal Republic of Germany
}

\section{Summary}

Mouse monoclonal antibody 4-I-244 detects a developmentally regulated antigen in embryos of Volvox carteri and inhibits specifically the morphogenetic process of Inversion (the process by which the embryo turns inside out). Antigen 4-1-244 was chemically characterized as a complex phytosphingolipid containing the neutral sugars xylose, galactose, and glucose as well as inositol and phosphate.

\section{Introduction}

The curling of cellular sheets in a spatially programmed manner is an ubiquitous process during embryogenesis of multicellular organisms. This process generates species-specific form. At the end of embryogenesis of the multicellular alga Volvox, a morphogenetic process of relative simplicity takes place which turns the embryo inside out ("inversion"). This inversion has successfully been used for a detailed geometric analysis. It has been demonstrated that the observed changes of cell shapes together with the locations of cell-cell connections are sufficient to account for the shape of the embryo at all stages of inversion (J. L. Kelland, [1964]. Ph. D. thesis, Princeton University, Princeton, NJ: Kelland, 1977; Pickett-Heaps, 1970; Viamontes and Kirk, 1977; Viamontes et al., 1979; Green et al., 1981).

The asexual organism of Volvox carteri consists of only two cell types: somatic and reproductive. Two thousand to four thousand somatic cells are located as a single layer on the surface of a hollow sphere (spheroid); 16 reproductive cells (gonidia) are positioned within the spheroid in the posterior region. The life cycle of $\mathrm{V}$. carteri has been repeatedly described in full detail (Starr, 1969, 1970).

Eleven or twelve rapid synchronous cleavage divisions of a gonidium generate all the cells of an adult spheroid. The resulting embryonic cells are arranged in a hollow sphere, but their orientation with respect to the surface is the reverse of that found in the adult: the flagellar ends of the somatic cells are directed toward the center of the sphere and gonidia protrude from the surface. During inversion, the embryo turns completely inside out through a cross-shaped slit (the "phialopore") and thereby establishes the adult configuration. Inversion is initiated when cells bordering the phialopore undergo a transition in shape and begin to resemble the classic "bottle cells" seen in a gastrulating amphibian embryo (Holtfreter, $1943,1944)$. The sequence of changes of cell shape pro- gresses in a wave-like fashion toward the pole opposite the phialopore.

Not surprisingly, the cell-shape changes accompanying inversion are mediated by the cytoskeleton (Viamontes et al., 1979). However, the control mechanism by which these cell-shape changes are initiated and precisely propagated are unknown.

In order to define extracellular molecules that might be involved in this mechanism, we prepared monoclonal antibodies against crude envelope fractions of inverting embryos and screened the resulting monoclonal antibodies for their capability to inhibit inversion in vivo. Antibody $4-1-$ 244 showed exactly this inhibitory action and in this paper we describe the characterization of the corresponding antigen.

\section{Results}

Monoclonal antibodies were raised against a crude membrane preparation from isolated Volvox carteri embryos at the stage of inversion. The resultant monoclonal antibodies were tested for their ability to interfere in vivo with the morphogenetic process of inversion. A single hybridoma line (4-1-244) produced an antibody exhibiting this inhibitory action (see Figure 1). If added to a population of synchronously developing embryos at least $3 \mathrm{hr}$ prior to the initiation of inversion, antibody 4-I-244 blocks nearly all embryos of the population from entering inversion. Thus the reproductive cells remain protruding from the embryonic surface (Figure 1, B1). This inhibition is specific in that further development of the reproductive cells proceeds normally. After maturation, the cells enter a new cycle of cell divisions and develop into daughter colonies which are now located outside the mother spheroid (Figure 1, B2). Antibody 4-I-244 does not interfere with any other developmental process if added during periods of the life cycle other than that preceding inversion. Antibody 4-I-244 was characterized as an IgM antibody. Therefore antibody 4-I-244 was cleaved to a mixture of monovalent and divalent antibodies by a recently introduced technique (Matthew and Reichardt, 1982). After cleavage, antibody $4-I-244$ fully retained its inhibitory action on the inversion process.

\section{Indirect Immunofluorescence Microscopy at Various Embryonic Stages}

Embryos fixed with formaldehyde at different stages of development were mixed and stained with monoclonal antibody 4-I-244 and fluorescein-conjugated sheep antimouse IgM. Early embryos (2- to 32-cell stage) did not bind antibody 4-I-244 appreciably, whereas all cell surfaces of late embryos (all stages beyond the 64-cell stage) were stained intensely (Figure 2). This finding suggests that antigen 4-I-244 is synthesized in a developmentally regulated fashion.

Another nine hybridoma lines obtained from the same 


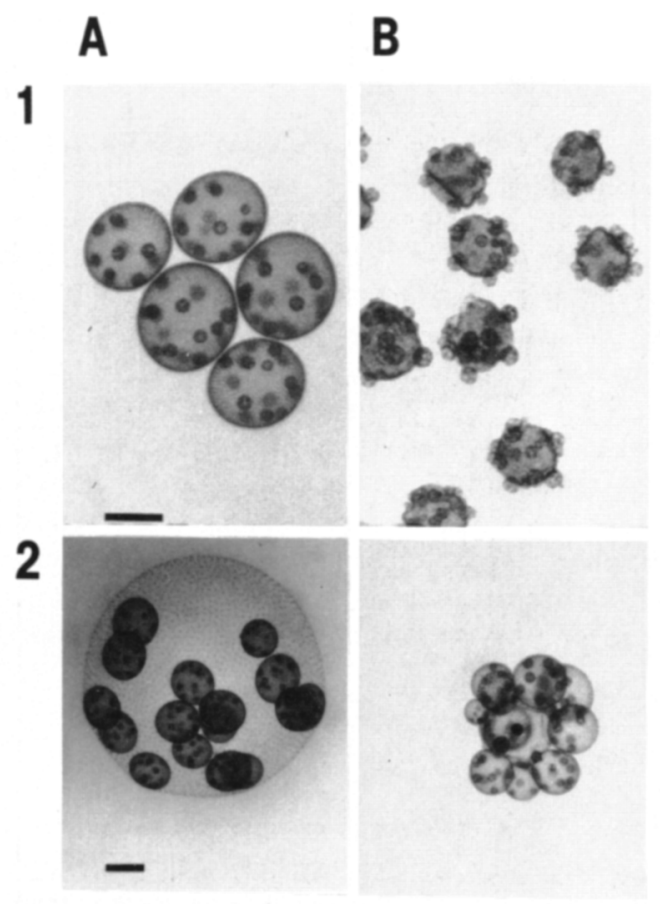

Figure 1. Monoclonal Antibody 4-1-244 Inhibits the Morphogenetic Process of Inversion

(A) Control culture of isolated embryos.

(B) Antibody $4-1-244(50 \mu \mathrm{g} / \mathrm{ml})$ added to isolated embryos $3 \mathrm{hr}$ prior to inversion.

Photographs were taken $10 \mathrm{hr}(1)$ and $50 \mathrm{hr}(2)$ after inversion. A tota of 52 monoclonal antibodies derived from the same fusion experiment were tested; only antibody 4-1-244 inhibited inversion. Bars $=100 \mu \mathrm{m}$

fusion experiment produced antibodies which stained the cell surface of embryos as intensely as did antibody $4-1$ 244. However, none of these nine monoclonal antibodies interfered with the process of inversion.

\section{Isolation of Antigen}

In a preliminary experiment, a lysate from inverting embryos was run on $6 \%$ and $15 \%$ SDS-polyacrylamide gels followed by blotting on a nitrocellulose filter. Antibody 4-I244 recognized a single component migrating within the low molecular weight range of the gels. There was absolutely no cross-reaction with any of the high molecular weight (glyco-) proteins, such as I-SG (Wenzl and Sumper, 1982), of Volvox carteri embryos. The antigenic component was completely resistant to proteolytic digestion. Furthermore, the antigen could be extracted into organic solvent mixtures. Complete extraction was achieved with chloroform:methanol:water (10:10:3). Thus the antigen behaves like a lipid with strong amphiphilic character. For further characterization of the antigen, an ultrasonic lysate from ${ }^{14} \mathrm{C}-\mathrm{NaHCO}_{3}$-labeled inverting embryos was dried and extracted with chloroform:methanol $(3: 2)$, followed by chloroform:methanol:water (10:10:3). The material of the latter extract was further separated by silica gel thin-layer chromatography, followed by blotting on a nitrocellulose filter and immunostaining with antibody 4-I-244

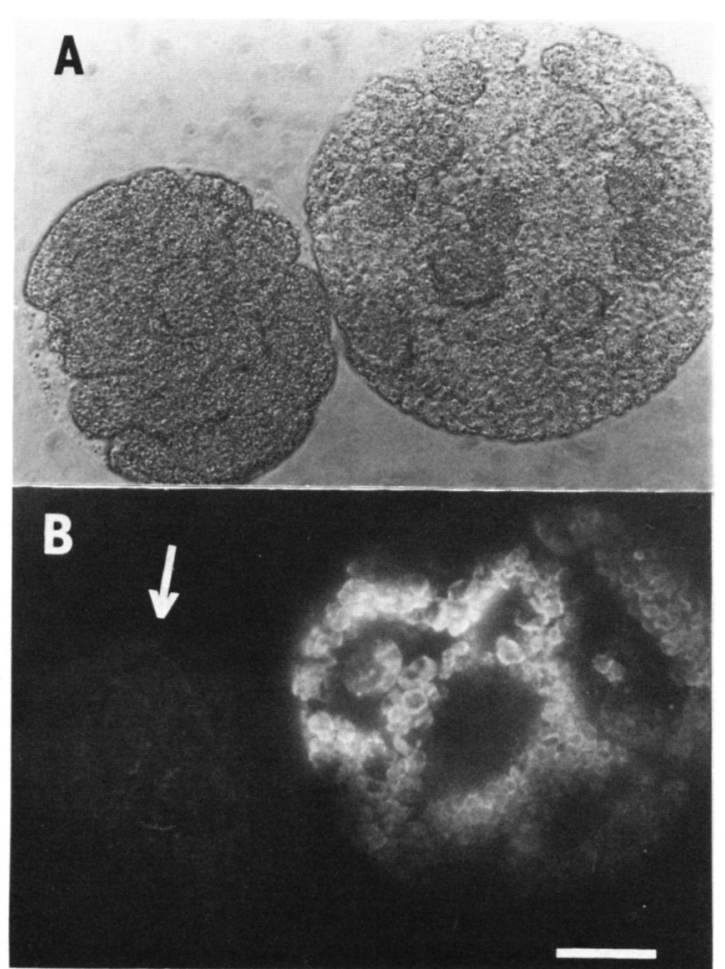

Figure 2. Expression of Antigen 4-I-244 by Volvox carteri Embryos a Different Cleavage Stages Studied by Indirect Immunofluorescence A mixture of early embryos (8- and 16-cell stage) and late embryos (>240-cell stage) was labeled with antibody (see Experimental Procedures). (A) Corresponding phase-contrast micrographs of fluorescence image (B) which shows an early (arrow) embryonic and a late embryonic stage. Bar $=25 \mu \mathrm{m}$.

(Figures 3A and 3B). Again, antibody 4-I-244 recognized only a single component. After elution from the thin-layer chromatogram, this component turned out to be homogeneous as judged by two-dimensional thin-layer chromatography (Figure 3C).

\section{Chemical Characterization of Antigen}

To obtain a first insight into the chemical structure of the antigen, homogeneous radioactive antigen (see Experimental Procedures) was subjected to acid hydrolysis (4-Ntrifluoroacetic acid, $4 \mathrm{hr}$ at $100^{\circ} \mathrm{C}$ ). The water soluble products were analyzed for the presence of neutral sugars by gas chromatography of the corresponding alditol acetates. As documented in Figure 4A, radioactive xylose, galactose, and glucose were detected in a ratio of about 2:1:1. No radioactive amino sugars could be found by radio gas chromatographic analysis, even after strong acid hydrolysis $\left(6-\mathrm{N}-\mathrm{HCl}, 6-12 \mathrm{hr}\right.$ at $\left.105^{\circ} \mathrm{C}\right)$ and subsequent conversion to $\mathrm{N}$-acetylhexosaminitol acetates (Michalski et al., 1984).

Radioactive material extractable into organic solvent from an acid hydrolysate was methylated and analyzed for the presence of fatty acids by radio gas chromatography. A single radioactive substance could be found (Flgure $4 C$ ) which on both polar (SP 2330) and nonpolar stationary phases (SE 30 ) cochromatographed with hexaeicosanoic 


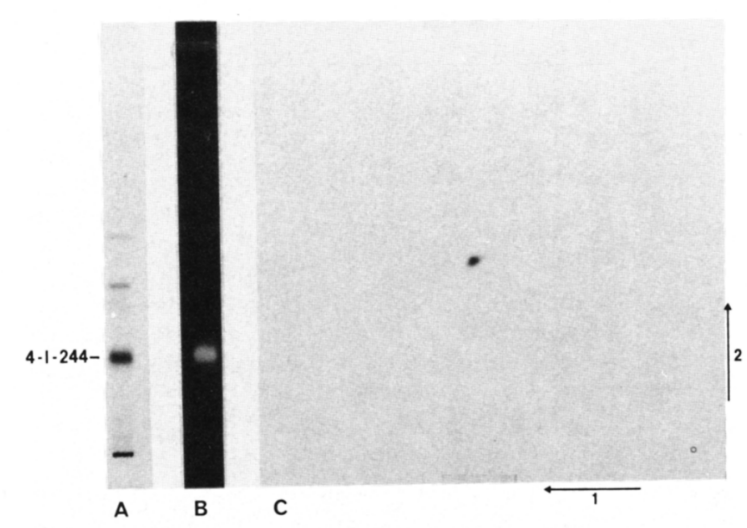

Figure 3. Thin-Layer Chromatography of Lipid Fractions Containing Antigen 4-I-244

(A) Chloroform:methanol:water (10:10:3) extract from ${ }^{14} \mathrm{C}$-labeled preinversion embryos (see Experimental Procedures) chromatographed on silica gel thin layers with solvent 1. Lipids were visualized by autoradiography.

(B) Immunostaining with antibody 4-I-244 of the same chromatogram after blotting on a nitrocellulose filter (see Experimental Procedures). (C) Autoradiogram of a two-dimensional thin-layer chromatogram of purified ${ }^{14} \mathrm{C}$-labeled antigen. First dimension: n-propanol:water (65: 35, v/v). Second dimension: n-butanol:pyridin:water (35:35:30, v/v). $0=$ origin.

acid methyl ester $\left(C_{26}\right)$. Next, the possible presence of long chain bases was investigated. For that purpose, the remaining material of the acid hydrolysate was brought to dryness, taken up in $50 \mathrm{mM} \mathrm{KOH}$, and extracted with ether. Again, radioactive material became extractable into the organic phase, indicating the presence of a long chain base. This was verified by the periodate/permanganate degradation of intact ${ }^{14} \mathrm{C}$-antigen. The degradation product obtained by extraction into organic solvent was identified as being mainly heptadecanoic acid (Figure 4D). Only minor amounts of pentadecanoic and nonadecanoic acid were also found. This result is indicative for the presence of a phytosphingosine with a main chain length of 20 $\mathrm{C}$-atoms in addition to traces of $\mathrm{C}_{18^{-}}$and $\mathrm{C}_{22}$-phytosphingosines (Kates, 1972).

Glycophytosphingosines characterized previously from yeast (Smith and Lester, 1974) and plant cells (Carter et al., $1958,1969)$ were shown to contain inositol bound to the long chain base via a phosphodiester bridge. The antigenic glycolipid from Volvox carteri was therefore also checked for the presence of inositol and phosphate. After strong acid hydrolysis $\left(6-\mathrm{N}-\mathrm{HCl}, 40 \mathrm{hr}\right.$ at $\left.105^{\circ} \mathrm{C}\right)$ of ${ }^{14} \mathrm{C}$ labeled antigen, inositol could indeed be detected by radio gas chromatography as its peracetylated derivative (Figure 4B). The presence of phosphate as a structural element of the antigen was demonstrated by incorporation of ${ }^{32}$-phosphate. After labeling of preinversion embryos with ${ }^{32}$ P-phosphate, the antigen was isolated to homogeneity as described for the ${ }^{14} \mathrm{C}$-labeled antigen. Autoradiography of two-dimensional silica gel thin-layer chromatograms confirmed a strong incorporation of $32 \mathrm{P}$-phiosphate into the antigen.

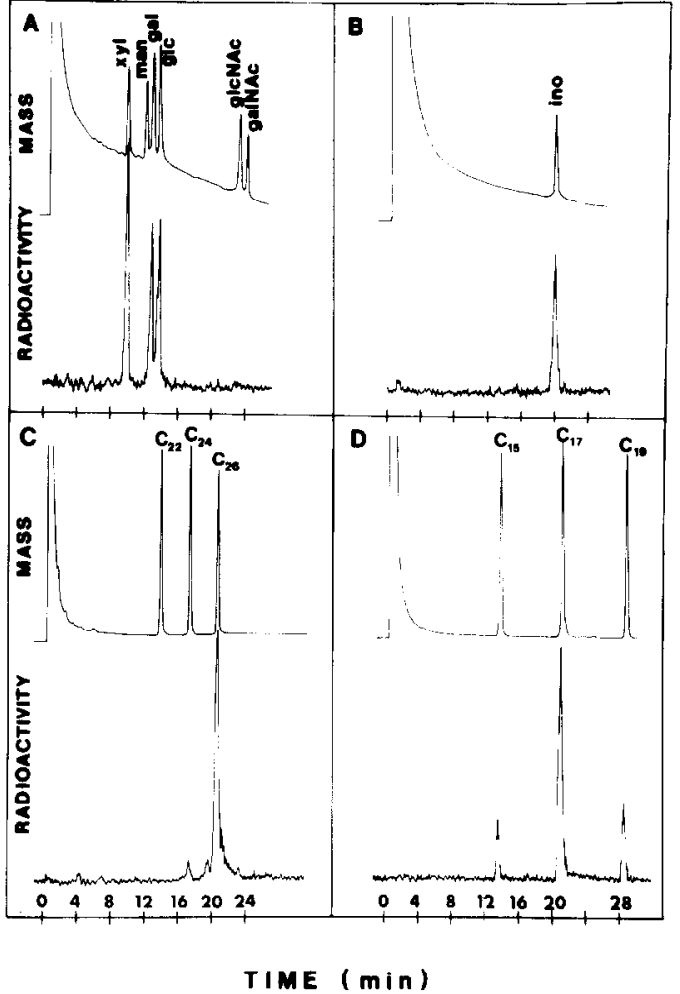

Figure 4. Chemical Characterization of ${ }^{14} \mathrm{C}$-Labeled Antigen 4-I-244 by Radio Gas Chromatography

The scan on top of each chromatogram records the mass signals of internal standard compounds.

(A) ${ }^{14} \mathrm{C}$-labeled alditol acetates derived from antigen 4-I-244 after acid hydrolysis.

(B) Identification of ${ }^{14} \mathrm{C}$-inositol acetate derived from the antigen after strong acid hydrolysis and peracetylation.

(C) Fatty acid methyl esters derived from the antigen after acid hydrolysis and methylation.

(D) Fatty acid methyl esters derived from the intact antigen after periodate-permanganate oxidation and subsequent methylation. Details are described in Experimental Procedures.

Taken together, the analytical data available thus far characterize the antigen as a phosphoglycolipid of the following type:

$$
\begin{aligned}
& \mathrm{CH}_{3}-\left(\mathrm{CH}_{2}\right)_{15}-\mathrm{CH}-\mathrm{CH}-\mathrm{CH}-\mathrm{CH}_{2}-\mathrm{O}-\text { (Phosphate, Inositol, 1-2 Xylose } \\
& \text { । | } 1 \text { Glucose, } 1 \text { Galactose) } \\
& \mathrm{OH} \mathrm{OH} \mathrm{NH} \\
& \mathrm{CO}-\left(\mathrm{CH}_{2}\right)_{24}-\mathrm{CH}_{3}
\end{aligned}
$$

Expression of Antigen 4-1-244 during Development Synthesis of antigen 4-I-244 was studied at different stages of development to confirm the observations made by in vivo experiments and indirect immunofluorescence. Synchronously developing Volvox carteri spheroids were dissociated at different stages of their life cycle and the embryos were pulse-labeled for $3 \mathrm{hr}$ with ${ }^{14} \mathrm{C}-\mathrm{NaHCO}_{3}$. After the pulse a chloroform:methanol:water (10:10:3) extract was prepared and analyzed by silica gel thin-layer 


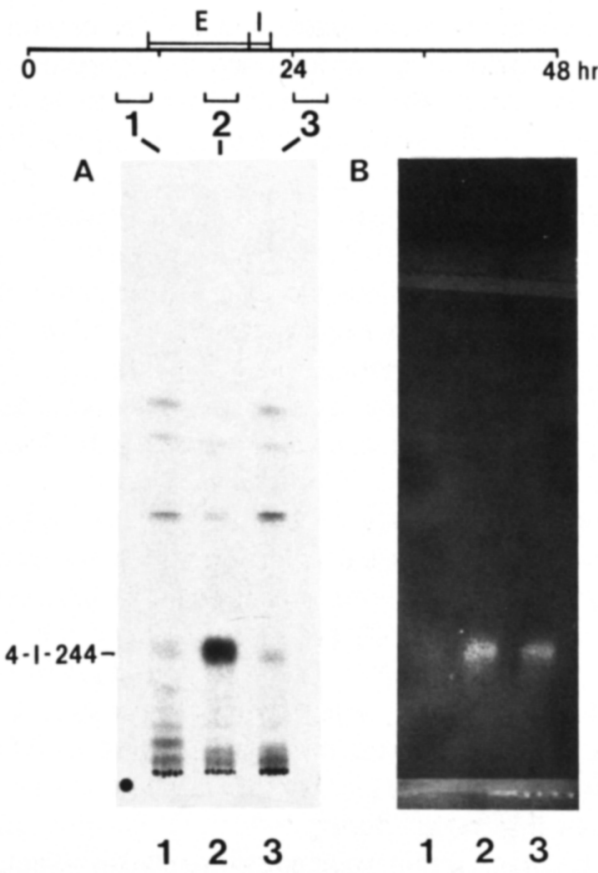

Figure 5. Expression of Antigen 4-I-244 in Asexual Embryos as a Function of Developmental Stage Analyzed by Thin-Layer Chromatography and Immunostaining

(A) Isolated uncleaved reproductive cells (1), preinversion embryos (2), and postinversion embryos (3) were pulse-labeled with ${ }^{14} \mathrm{C}-\mathrm{NaHCO}_{3}$ $(3 \mathrm{hr})$ and the chloroform:methanol:water (10:10:3) extract $(40,000 \mathrm{cpm}$ each) analyzed by thin-layer chromatography (solvent 1) and autoradiography (see Experimental Procedures).

(B) The same chromatogram was blotted on a nitrocellulose filter and immunostained with antibody 4-1-244.

The drawing on top of the chromatograms shows a time scale of the life cycle of asexually growing $V$. carteri. The periods of pulse labeling are marked.

chromatography for the presence of antigen 4-|-244. Autoradiography reveals no detectable synthesis in uncleaved reproductive cells (Figure 5, lane 1). A high rate of synthesis of antigen was observed 3-4 hr immediately preceding the initiation of inversion (Figure 5, lane 2). Shortly after termination of inversion, the rate of synthesis of antigen 4-I-244 drops markedly (lane 3) whereas other lipid components continue to be synthesized at essentially unchanged rates. The same thin-layer chromatogram was blotted onto a nitrocellulose filter. Antibody 4-1-244 detected antigen only at late embryonic stages and at stages following inversion (Figure 5B). Thus antigen 4-I-244 remains stable for at least $4 \mathrm{hr}$ after synthesization.

A unique feature of sexual development in the male strain (69-1b) that leads to sperm-cell-containing Volvox carteri spheroids is the occurrence of an additional morphogenetic process: in the first inversion process the embryo turns inside out exactly as during asexual development. Afterward ( $20 \mathrm{hr}$ later) each reproductive cell (now called an androgonidium) undergoes a series of cleavages to form a packet of sperm cells. This bowl-shaped sperm cell mass again performs a morphogenetic process (second inversion) to form a sperm bundle which is

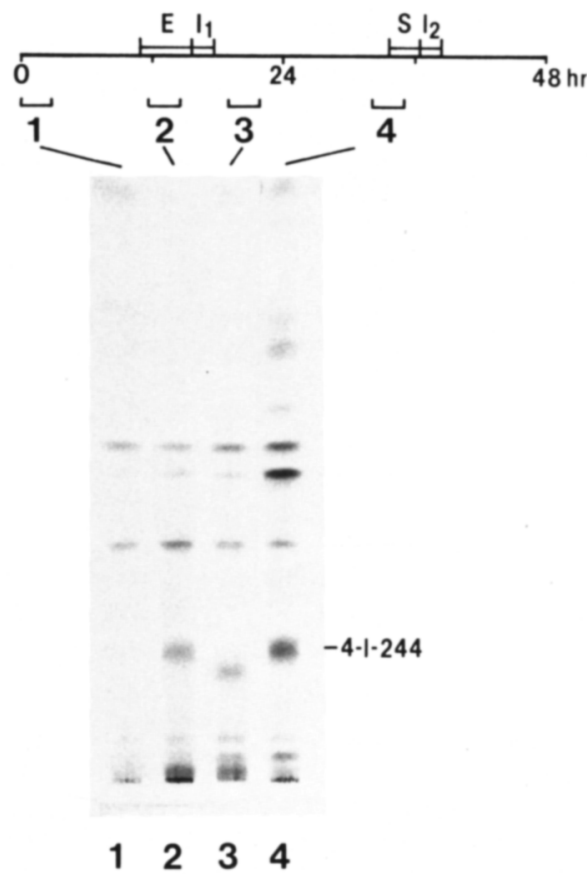

Figure 6. Expression of Antigen 4-1-244 in Sexual Male Embryos (strain 69-1b) as a Function of Developmental Stage Analyzed by Pulse Labeling and Thin-Layer Chromatography

Isolated uncleaved reproductive cells (1), preinversion embryos (2), postinversion embryos (3), and isolated preinversion sperm packets (4) were pulse-labeled with ${ }^{14} \mathrm{C}-\mathrm{NaHCO}_{3}(3 \mathrm{hr})$ and the glycolipid fraction $(40,000 \mathrm{cpm}$ each) applied to silica gel thin layers (solvent 1). Autoradiography was overnight. The drawing on top of the chromatograms shows a time scale of the life cycle of sexually growing V. carteri (691b). The periods of pulse labeling are marked.

convex on its anterior side (Birchem and Kochert, 1979). A functional role for antigen $4-1-244$ in the inversion process would become even more likely if its synthesis were reinitiated within sperm packets at the time of this second inversion. ${ }^{14} \mathrm{C}-\mathrm{NaHCO}_{3}$ pulse-labeling experiments over the whole life cycle of sexually induced male embryos clearly show that antigen 4-I-244 is indeed synthesized during both the first and second preinversion period (Figure 6, lanes 2 and 4). Furthermore, antigen 4-I-244 is produced within the isolated sperm packets during the second inversion process (Figure 6, lane 4).

\section{Localization of Antigen Synthesis within a \\ Volvox carteri Spheroid}

All experiments described so far were done with isolated gonidia or embryos at various developmental stages with the assumption that only these reproductive units are synthesizing antigen 4-I-244. The experiment described in Figure 5 gave essentially the same result when performed with intact Volvox carteri spheroids containing embryos at corresponding developmental stages.

To exclude antigen synthesis by somatic cells of the mother colony, Volvox carteri spheroids containing preinversion embryos were pulse-labeled with ${ }^{14} \mathrm{C}-\mathrm{NaHCO}_{3}$ and dissociated mechanically into somatic cell sheets and free embryos (see Experimental Procedures). The so- 


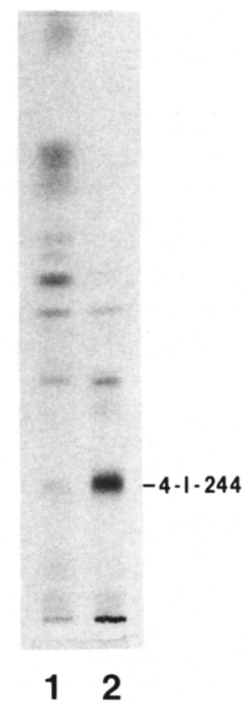

Figure 7. Localization of Newly Synthesized Antigen 4-I-244 within a Volvox carteri Spheroid

Synchronously developing Volvox carteri spheroids containing preinversion embryos were pulse-labeled with ${ }^{14} \mathrm{C}-\mathrm{NaHCO}_{3}(3 \mathrm{hr})$ and then dissociated into somatic cells and embryos (see Experimental Procedures). A chloroform:methanol:water (10:10:3) extract $(40,000 \mathrm{cpm}$ each) of both cell fractions was analyzed by thin-layer chromatography (solvent 1) and autoradiography. (1) somatic cell extract. (2) embryonic cell extract.

matic cell sheets of the mother spheroid were separated from the embryos by differential sieving. The glycolipids of both cellular fractions were then extracted and analyzed by thin-layer chromatography (Figure 7). Nearly all of the labeled antigen was associated with the embryo fraction, indicating that antigen $4-I-244$ is mainly synthesized within preinversion embryos. Thus antigen 4-I-244 is produced in both a spatially and temporarlly controlled fashion.

\section{Discussion}

Antigen 4-I-244 turned out to be a complex sphingolipid containing phosphate and inositol and the neutral sugars xylose, galactose, and glucose. In a previous work, in which the main lipid components of Volvox carteri were characterized (Moseley and Thompson, 1980), this type of lipid remained undetected, indicating that this lipid class represents only a minor constituent of Volvox carteri membranes. To estimate what percentage of total lipid antigen 4-1-244 is, we determined the ratio of $C_{16}$ plus $C_{18}$ fatty acids (the main constituents of Volvox carteri lipids) and $\mathrm{C}_{26}$ fatty acid (the constituent of antigen 4-I-244) by gas chromatographic analysis after hydrolysis of total lipid extracts. From this analysis, antigen 4-I-244 represents less than $0.2 \%$ of total Volvox carteri lipids.

The Volvox carteri sphingolipid superficially resembles the complex phosphorus-containing glycolipids that had been isolated and characterized by Carter and associates $(1958,1969)$ from plant material. These compounds were called phyto-glycolipids. The remarkable similarity in gen- eral structure between plant and animal cerebrosides suggests similar functions for these sphingoglycolipids in plant and animal cell membranes. Growing evidence supports the idea that these lipids are extremely important in a number of specialized functions. For instance, the ganglioside GQ1b enhances greatly neurite outgrowth and cell proliferation in neuroblastoma cell lines (Tsuji et al., 1983). Gangliosides detected by a monoclonal antibody were shown to be developmentally regulated in chicken retina and brain (Grunwald et al., 1985), and a phosphorylated ganglioside was reported to stimulate species-specific adhesion of chicken hepatocytes (Roseman, 1985).

Monoclonal antibody 4-I-244 specifically inhibits the morphogenetic process of inversion during Volvox carteri embryogenesis. However, this specific inhibitory action does not unequivocally prove a functional role of this glycolipid during inversion. We cannot exclude the possibility that the inhibitory action is due to an unspecific steric hindrance or due to crosslinking caused by antibody binding to the cell surface that might interfere with cell-shape changes that occur during inversion. Several observations, however, argue against an unspecific effect:

-Antigen 4-I-244 is a developmentally regulated glycolipid, i.e., it is only synthesized during a rather limited period of the Volvox carteri life cycle and this period coincides with the preinversion stage.

-Synthesis of antigen 4-I-244 is locally restricted, taking place within the preinversion embryo.

- The different developmental program of sexually induced males includes a second inversion event, taking place within the sperm cell packets. Again, coinciding with the latter event, synthesis of antigen 4-I-244 is initiated within sperm packets at a high rate.

-Antibody 4-I-244 does not inhibit any other developmental event of the Volvox carteri life cycle. Even in the permanent presence of this monoclonal antibody, Volvox carteri develops completely normally except for the inversion process. If antibody is added immediately after the inversion event, development again continues completely undisturbed.

-After cleavage into small fragments, IgM-antibody 4-I244 retains its inhibitory action on the inversion process.

The last cell division during embryogenesis was shown to have finished between 50 and 100 min before inversion. During this time a cell-shape change from pear- to spindle-shaped occurs within the embryo. To elicit full inhibition of inversion, antibody 4-1-244 must not be added later than about $120 \mathrm{~min}$ before inversion. This observation suggests that antibody 4-I-244 interferes with an early event of the inversion process.

The immunofluorescence data demonstrate that antigen 4-I-244 is accessible and therefore associated with the external surface of the embryonic cells. Previously, we characterized an extracellular sulfated glycoprotein (I-SG) which is likely to have a function during inversion (Wenzl and Sumper, 1982). These observations indicate that, besides the cytoskeleton, a number of extracellular mole- 
cules seem to be involved, suggesting a mechanism of transmembrane coordination of cytoskeletal components.

\section{Experimental Procedures}

\section{Culture Conditions}

Volvox carteri f. nagariensis, strains HK 10 (female) and 69-1b (male) were obtained from the Culture Collection of Algae at the University of Texas at Austin (R. C. Starr). Synchronous cultures were grown in Volvox medium (Provasoli and Pintner, 1959) at $28^{\circ} \mathrm{C}$ in an $8 \mathrm{hr}$ dark/16 hr light (10,000 lux) cycle (Starr and Jaenicke, 1974).

\section{Isolation of Volvox carterl Embryos}

The following procedure refers to cleaving embryos. Slightly different experimental conditions are required for the isolation of uncleaved embryos (gonidia) which are given in brackets. Spheroids at the appropriate developmental stage were disrupted by forcing them through a 0.5 $\mathrm{mm}(0.4 \mathrm{~mm})$ hypodermic needle. The suspension was filtered through a $90 \mu \mathrm{m}$ mesh nylon cloth through which only free embryos and single somatic cells pass. Embryos were collected on a $40 \mu \mathrm{m}(10 \mu \mathrm{m})$ mesh nylon cloth, which retains only embryos. Subsequently, the embryo suspension was allowed to settie several times and the supernatant, which might contain some somatic cell sheets, was discarded each time.

\section{Preparation of the Immunogen}

Inverted embryos of about 8000 Volvox carteri spheroids were isolated and disintegrated by ultrasonic treatment ( $30 \mathrm{sec}$ total). The lysate $(0.5$ $\mathrm{ml}$ ) was layered over a $3 \mathrm{ml}$ cushion of $20 \%$ sucrose in Volvox carter medium. Centrifugation was at $100,000 \mathrm{~g}$ for $3 \mathrm{hr}$. The green pellet was dissolved in $300 \mu \mathrm{l}$ in phosphate-buffered saline containing $1 \%$ SDS and heated at $95^{\circ} \mathrm{C}$ for $2 \mathrm{~min}$. One hundred and fifty microliters were mixed with the same volume of the appropriate adjuvant for one immunization.

\section{Preparation of Monoclonal Antlbodles}

BALB/c mice were immunized by intraperitoneal injections of a crude membrane fraction from Volvox carteri embryos at the developmental stage of inversion with Freund's complete adjuvant. Six weeks later an intraperitoneal boost of the same immunogen with Freund's incomplete adjuvant was given followed by fusion with NSO/U myeloma cells (Clark, Wright, and Milstein, unpublished results) four days later. Hybridomas interfering with the morphogenetic event of inversion were detected in an in vivo assay. About 100 isolated Volvox carteri embryos in $0.5 \mathrm{ml}$ Volvox carteri medium were incubated with $100 \mu \mathrm{l}$ concentrated hybridoma culture supernatants $4 \mathrm{hr}$ before the onset of inversion: $0.45 \mathrm{ml}$ culture fluid aliquots were precipitated by the addition of $0.55 \mathrm{ml}$ of saturated ammonium sulfate, followed by centrifugation and resuspension of the pellet in $0.1 \mathrm{ml}$ Volvox carteri medium (concentration factor about 5), and dialysed against the same medium overnight. Ten hours after inversion all samples were checked for abnormal inversion by inspection under a stereo microscope. Positive hybridomas were cloned under microscopic observation by deposition of small droplets into microtiter plates. To droplets containing only one cell, medium with macrophages was added (Ochiai et al., 1982). Determination of antibody class was done via Ouchterlony analysis. Antibody 4-1-244 (IgM) was precipitated from hybridoma culture supernatants by $55 \%$ saturation of ammonium-sulfate, dialysed against $0.14 \mathrm{M}$ phosphate buffer ( $\mathrm{pH} 8.0$ ) (Ochiai et al., 1982), and purified by protein-Asepharose column chromatography (Pharmacia, Uppsala). Antibody was eluted with $0.1 \mathrm{M}$ acetic acid containing $0.15 \mathrm{M} \mathrm{NaCl}$.

\section{Isolation of ${ }^{14} \mathrm{C}$-Laboled Antlgen 4-1-244}

For chemical characterization via radio gas chromatography, isolated embryos ( $4 \mathrm{hr}$ before the onset of inversion) of about 8000 Volvox carteri spheroids were suspended in $2 \mathrm{ml} \mathrm{Na-glycerophosphate-free} \mathrm{Vol-}$ vox carteri medium. After addition of $400 \mu \mathrm{Ci}(15 \mathrm{MBq}){ }^{14} \mathrm{C}-\mathrm{NaHCO}_{3}$ the suspension was shaken under illumination (10000 lux) in a water bath at $27^{\circ} \mathrm{C}$ for $3 \mathrm{hr}$. ${ }^{14} \mathrm{C}$-labeled embryos were disintegrated by ultrasonic treatment ( $30 \mathrm{sec}$ total). The lysate was dried and extracted four times with $0.8 \mathrm{ml}$ chloroform:methanol (3:2). Antigen was then extracted twice with $0.4 \mathrm{ml}$ chloroform:methanol:water (10:10:3). The latter extracts were pooled, dried, and the material was dissolved in 50 $\mu \mathrm{l}$ propanol:water 65:35 and applied to silica gel thin layers (Kieselgel 60: Merck, Darmstadt). Chromatography was performed with solvent 1: chloroform:methanol:4 $\mathrm{N}$ ammonium hydroxide $(9: 7: 2 \mathrm{v} / \mathrm{V})$ with 0.2 $\mathrm{M}$ ammonium acetate (Kaul and Lester, 1975). After autoradiography antigen 4-1-244 was localized either by immunoblotting or by comparison with authentic antigen run on the same chromatogram. The antigen containing area was scraped off and the antigen eluted with propanol:water 65:35 and rechromatographed on a silica gel thin layer in propanol:water 65:35. After autoradiography antigen 4-1-244 was isolated as described for the first chromalography. Antigen 4-1-244 was homogeneous as checked by two-dimensional thin-layer chromatography on silica gel plates.

\section{Chemical Characteristics}

Radio gas chromatography was performed with a Packard 423 gas chromatograph. The outlet end of the column was fitted with a 1:10 stream splitter: the radioactivity of 0.9 of the sample was measured as ${ }^{14} \mathrm{CO}_{2}$ in a Packard model 894 gas proportional counter. One tenth of the sample served for mass detection (FID) of internal standards.

\section{Carbohydrate Analysis}

Neutral and amino sugars were analyzed by GLC as their alditol acetates (Laine et al., 1972; Spiro, 1972) on a $1 \mathrm{~m} \times 2 \mathrm{~mm}$ glass column (3\% SP-2340 on 100/120 Supelcoport, Supelco) with a linear temperature program from $180^{\circ} \mathrm{C}$ to $265^{\circ} \mathrm{C}(4 \% \mathrm{~min})$. Samples were hydrolyzed in 4-N-trifluoroacetic acid for various times at $100^{\circ} \mathrm{C}$.

Fatty Acid Analysis

${ }^{14} \mathrm{C}$-labeled lipid was hydrolyzed in conc. $\mathrm{HCl}: \mathrm{CH}_{3} \mathrm{OH}: \mathrm{H}_{2} \mathrm{O}$ (3:29:4, $\mathrm{v} / \mathrm{v}$ ) at $80^{\circ} \mathrm{C}$ for $18 \mathrm{hr}$ (Carter and Hirschberg, 1968). Free fatty acids and their methylesters were extracted into petroleum ether and after the addition of appropriale unlabeled reference acids $(20 \mu \mathrm{g} \mathrm{each})$ the extract was dried and treated with $50 \mu \mathrm{l}$ Methyl-8 (Sigma) at $60^{\circ} \mathrm{C}$ for $15 \mathrm{~min}$ to ensure complete methylation. GLC was performed either on a $2 \mathrm{~m} \times 2 \mathrm{~mm} 10 \%$ SP 2330 (Supelco) glass column (temperature program $180^{\circ} \mathrm{C}$ to $240^{\circ} \mathrm{C}$ with $3^{\circ} \mathrm{C} / \mathrm{min}$ ) or on a $2 \mathrm{~m} \times 2 \mathrm{~mm} 3 \%$ SE-30 (Sulpelco) glass column (temperature program $210^{\circ} \mathrm{C}$ to $290^{\circ} \mathrm{C}$ with $\left.4^{\circ} \mathrm{C} / \mathrm{min}\right)$.

\section{Inositol Dotormination}

Inositol was estimated gas chromatographically after strong acid hydrolysis according to Wells et al. (1985) as modified by Smith and Lester (1974). After peracelylation inositol was identified on a 3\% SP2340 (Supelco) $1 \mathrm{~m} \times 2 \mathrm{~mm}$ glass column as described for sugar analysis.

\section{Perlodate-Permanganate Oxidation of Intact Antigen}

Long chain bases were characterized by identification of the fatty acids formed after a permanganate-periodate oxidation (Von Rudioff, 1956) of intact lipids by the modified procedure of Youngs and Subbaram (1964). To samples of ${ }^{14} \mathrm{C}$-labeled antigen and standard phytosphingosine $(100 \mu \mathrm{g}) 150 \mu \mathrm{l}$ tert-butanol, $40 \mu \mathrm{l}$ of $\mathrm{H}_{2} \mathrm{O}$ and $10 \mu \mathrm{l}$ of $\mathrm{K}_{2} \mathrm{CO}_{3}(8$ $\mathrm{mg} / \mathrm{ml}$ ) were added. To this solution was added $50 \mu \mathrm{l}$ of the oxidizing mixture: $0.21 \mathrm{~g} \mathrm{NaIO}_{4}, 0.25 \mathrm{ml}$ of $0.1 \mathrm{M} \mathrm{KMnO}_{4}$ and $\mathrm{H}_{2} \mathrm{O}$ to $10 \mathrm{ml}$. After $1 \mathrm{hr}$ at $65^{\circ} \mathrm{C}$ another $20 \mu \mathrm{l}$ of the oxidizing mixture was added and incubation continued for another $1.5 \mathrm{hr}$. The reaction was stopped by the addition of $3 \mu$ lethylene glycol $\left(1 \mathrm{hr}, 60^{\circ} \mathrm{C}\right)$. The solution was evaporated to approximately $50 \mu \mathrm{l}$ and $1 \mu \mathrm{l}$ conc. $\mathrm{HCl}$ was added. Fatty acids were extracted with petroleum ether, methylated, and analyzed by GLC. (2 $\mathrm{m} \times 2 \mathrm{~mm} 3 \%$ SE-30 glass column, temperature program $160^{\circ} \mathrm{C}$ to $260^{\circ} \mathrm{C}$ with $2^{\circ} \mathrm{C} / \mathrm{min}$ ).

Analysis of the Expression of Antigen 4-1-244 during Development The embryos of about 1500 Volvox carteri spheroids at the appropriate developmental stage were isolated as described and suspended in 0.5 $\mathrm{ml}$ Na-glycerophosphate-free Volvox medium. "Pulse"-labeling (3 hr) with $100 \mu \mathrm{Ci}(4 \mathrm{MBq}){ }^{14} \mathrm{C}-\mathrm{NaHCO}_{3}$ and extraction was performed as described. Aliquols of the chloroform:methanol:water (10:10:3) extract corresponding to $40,000 \mathrm{cpm}$ were subjected to thin-layer chromatography on silica gel in chloroform:methanol:4-N-ammoniumhydroxide with $0.2 \mathrm{M}$ ammonium acetate (solvent 1). Labeled lipids were visualized by autoradiography (overnight). Antigen 4-1-244 was identified by comparison with authentic material or by immunological detection after blotting onto nitrocellulose filters.

Immunodetection of Blotted Lipids

${ }^{14} \mathrm{C}$-labeled lipids were transfered to nitrocellulose filters (BA 85; Schleicher \& Schuell, Dassel) as described by Towbin et al. (1984). 
Filters were incubated in ammonium-sulfate-precipitated hybridoma culture fluid of hybridoma $4-1-244$ and subsequently in $0.02 \mathrm{mg} / \mathrm{ml}$ FITC-labeled anti-mouse lgM from sheep (Sigma, Munich). The blots were inspected under monochromatic light of $490 \mathrm{~nm}$ produced by an interference filter (Schott, Mainz) through a $530 \mathrm{~nm}$ cut-off filter (Schott, Mainz). Photographs were taken using Ilford HP 5 film.

\section{Fluorescence Microscopy}

Isolated Volvox carteri embryos from various developmental stages were mixed and fixed in $2 \%$ paraformaldehyde for $15 \mathrm{~min}$ at $20^{\circ} \mathrm{C}$. After washing with Tris-saline $(\mathrm{pH} 8.0)$ and $50 \mathrm{mM}$ glycine $(\mathrm{pH} \mathrm{8.0)}$ the embryos were labeled with $0.01 \mathrm{mg} / \mathrm{ml}$ of monoclonal antibody $4-1-244$ in the presence of $1 \mathrm{mg} / \mathrm{ml}$ horse $\mathrm{lgG}$ for $45 \mathrm{~min}$ at $20^{\circ} \mathrm{C}$. After washing, $0.01 \mathrm{mg} / \mathrm{mI}$ FITC conjugated anti-mouse IgM from sheep (Sigma) in 5\% horse serum was applied for $60 \mathrm{~min}$. Labeled embryos were washed and viewed using a Leitz fluorescence microscope. Photographs were taken using Ilford HP 5 film.

\section{Acknowledgments}

Our work was supported by the Deutsche Forschungsgemeinschaft (SFB 43). We wish to thank Dr. Gerisch Martinsried, who helped us to establish monoclonal antibody techniques. We appreciate the excellent technical assistance of Brigitte Seidel and Ulrike Stöeckl. We are grateful to Manuela Biederer for cultivating hybridomas.

The costs of publication of this article were defrayed in part by the payment of page charges. This article must therefore be hereby marked "advertisement" in accordance with 18 U.S.C. Section 1734 solely to indicate this fact.

Received March 3, 1986; revised April 23, 1986.

\section{References}

Birchem, R., and Kochert, G. (1979). Development of sperm cells of Volvox carteri f. weismannia (Chlorophyceae). Phycologia 18, 409-419. Carter, H. E., and Hirschberg, C. B. (1968). Phytosphingosines and branched sphingosines in kidney. Biochemistry 7, 2296-2300.

Carter, H. E., Celmer, W. D., Galanos, D. S., Gigg, R. H., Lands, W. E. M., Law, J. H., Mueller, K. L., Nakayama, T., Tomizawa, H. H. and Weber, E. (1958). Biochemistry of sphingolipides. X. Phytoglycolipide, a complex phytosphingosine-containing lipid from plant seeds. J. Amer. Oil Chem. Soc. 35, 335-343.

Carter, H. E., Strobach, D. R., and Hawthorne, J. N. (1969). Blochemistry of the sphingolipids. XVIII. Complete structure of tetrasaccharide phytoglycolipid. Biochemistry 8, 383-388.

Green, K. J., Viamontes, G. I., and Kirk, D. L. (1981). Mechanism of formation, ultrastructure, and function of the cytoplasmatic bridge system during morphogenesis in Volvox. J. Cell Biol. 91, 756-769.

Grunwald, G. B., Fredman, P., Magnani, J. L., Trisler, D., Ginsburg, V., and Nirenberg, M. (1985). Monoclonal antibody $18 B 8$ detects gangliosides associated with neuronal differentlation and synapse formation. Proc. Natl. Acad. Sci. USA 82, 4008-4012.

Holtfreter, J. (1943). A study of the mechanics of gastrulation. Part I J. Exp. Zool. 94, 261-318.

Holtfreter, J. (1944). A study of the mechanics of gastrulation. Part II. J. Exp. Zool. 95, 171-212.

Kates, M. (1972). Techniques of lipidology: isolation, analysis and identification of lipids. In Laboratory Techniques in Biochemistry and Molecular Biology, T. S. Work and E. Work, eds. (New York: NorthHolland), pp. 279-579.

Kaul, K., and Lester, R. L. (1975). Characterization of inositol-containing phosphosphingolipids from tobacco leaves. Plant Physiol. 55, 120-129.

Kelland, J. L. (1977). Inversion in volvox (Chlorophyceae). J. Phycol. 13, 373-378.

Laine, R. A., Esselman, W. J., and Sweeley, C. C. (1972). Gas-liquid chromatography of carbohydrates. Meth. Enzymol. 28, 159-167.

Matthew, W. D., and Reichardt, L. F. (1982). Development and application of an efficient procedure for converting mouse lgM into small, active fragments. J. Immunol. Meth. 50, 239-253.
Michalski, J., Peter-Katalinic, J., Egge, H., Paze-Parente, J., Montreuil J., and Strecker, G. (1984). Behavior of the 2-acetamido-2-deoxy-Dglucopyranosyl residue during sequential hydrozinolysis, N-reacetylation, reduction, and methylation of glycoasparagines. Carbohydr. Res. 134, $177-189$.

Moseley, K. R., and Thompson Jr., G. A. (1980). Lipid composition and metabolism of Volvox carteri. Plant Physiol. 65, 260-265.

Ochiai, H., Schwarz, H., Merkl, R., Wagle, G., and Gerisch, G. (1982) Stage-specific antigens reacting with monoclonal antibodies against contact site A, a cell-surface glycoprotein of Dictyostelium discoideum. Cell Differ. 11, 1-13.

Pickett-Heaps, J. D. (1970). Some ultrastructural features of Volvox, with particular reference to the phenomenon of inversion Planta 90 174-190.

Provasoli, L., and Pintner, I. J. (1959). Artificial media for freshwater algae: problems and suggestions. In The Ecology of Algae, Special Pub lication No. 2, Pymatuning Laboratory of Field Biology, C. A. Tyron and R. T. Hartman, eds. (Pittsburgh: University of Pittsburgh), pp. 84-96. Roseman, S. (1985). Studies on specific intercellular adhesion. J. Biochem. 97, 709-718.

Smith, S. W., and Lester, R. L. (1974). Inositol-phosphoryl ceramide, a novel substance and the chlef member of a major group of yeast sphingolipids containing a single inositol phosphate. J. Biol. Chem. 249, 3395-3405.

Spiro, R. G. (1972). Study of the carbohydrate of glycoproteins. Meth. Enzymol. 28, 3-43.

Starr, R. C. (1969). Structure, reproduction, and differentiation in Volvox carteri f. nagariensis lyengar, strains Hk 9 \& 10. Arch. Protistenk. 111, 204-222.

Starr, R. C. (1970). Control of differentiation in Volvox. Dev. Biol. Suppl. 4, 59-100.

Starr, R. C., and Jaenicke, L. (1974). Purification and characterization of the hormone initiating sexual morphogenesis in Volvox carteri $f$. nagariensis Jyengar. Proc. Natl. Acad. Sci. USA 77, 1050-1054.

Towbin, H., Schoenenberger, C., Ball, R., Braun, D. G., and Rosenfelder, G. (1984). Glycosphingolipid-blotting: an immunological detection procedure after separation by thin layer chromatography. J. Immunol. Meth. 72, 471-479.

Tsuji, S., Arita, M., and Nagai, Y. (1983). GQ1b, a bioactive ganglioside that exhibits novel nerve growth factor (NGF)-like activities in the two neuroblastoma cell lines. J. Biochem. 94, 303-306.

Viamontes, G. I., and Kirk, D. L. (1977). Cell shape changes and the mechanism of inversion in Volvox. J. Cell Biol. 75, 719-730.

Viamontes, G. I., Fochtmann, L. J., and Kirk, D. L. (1979). Morphogenesis in Volvox: analysis of critical variables. Cell 17, 537-550.

Von Rudloff, E. (1956). Periodate-permanganate oxidations. V. Oxidation of lipids in media containing organic solvents. Can. J. Chem. 34 1413-1418.

Wells, W. W. Pittman, T. A., and Wells, H. J. (1965). Quantitative analysis of myoinositol in rat tissue by gas-liquid chromatography. Anal. Biochem. 10, 450-458.

Wenzl, S., and Sumper, M. (1982). The occurrence of different sulphated cell surface glycoproteins correlates with defined developmental events in Volvox. FEBS Lett. 143, 311-315.

Youngs, C. G., and Subbaram, M. R. (1964). Determination of the glyceride structure of fats: gas-liquid chromatography of oxidized glycerides. J. Amer. Oil Chem. Soc. 41, 218-221. 